\title{
Pig heart transplant 'breakthrough' stirs debate over timing of trials
}

London. A British biotechnology company last week announced that it had achieved a major step towards the successful implantation of pig hearts into humans by breeding a transgenic pig whose organs can block the action of a key protein responsible for transplant rejection.

David White, co-founder and medical director of Imutran, based near Cambridge, told a press conference in London that 10 monkeys, each of which had been given a heart from one of the company's herd of transgenic pigs, had already survived for an average of 40 days, and that two were still alive more than 60 days after the operation.

The news that the company appears to have successfully developed a technique for combatting one of the major hurdles in xenotransplantation, the so-called 'hyperacute rejection' (HAR), has been widely welcomed among researchers in the field.

"It is a real step forward; I am very excited," says Fritz Bach, of the Harvard Medical School's Sandoz Centre for Immunobiology. Bach was one of the first to show that the failure of untreated organs to suppress the action of human complement is a major factor responsible for the rejection of donor organs.

There was a similar welcome to Imutran's news from transplant surgeons, currently squeezed between an increasing demand for transplants - in Britain, over 6,000 people

\section{Astronomers keep an eye on the sky}

Boston. Astronomers are pushing ahead with plans to search for Near-Earth Objects (NEOs), despite a decision last month by the US National Aeronautics and Space Administration (NASA) not to finance an expanded hunt for asteroids and comets on a potential collision course with Earth.

A 90-cm telescope at the Observatoire de la Cìte d'Azur in Caussols, France, should become the next instrument to be used in this search. This will be followed by LONEOS, a new programme at the Lowell Observatory in the United States, and another survey that would make use of the US Air Force telescope network known as GEODSS (Ground-based Electro-Optical Deep Space Surveillance).

"We don't need to wait for a \$42-million programme," says Alain Maury of the Cite d'Azur observatory, referring to the recommendations of the so-called Shoemaker Report that were recently rejected by NASA. "We can do a good job for much less making use of the telescopes available to us now." are currently waiting for organs to become available, and in the United States the number is more than 30,000 - and a declining supply of suitable organs from human donors.

Speaking at last week's meeting of the British Association in Newcastle, for example, Michael Thick, a local transplant surgeon, said that he and his colleagues were "waiting with bated breath for the case to be proven in clinical trials".

At the same time, however, opinion is divided among researchers over the speed with which the company says that it now intends to move on to clinical trials, given in particular the fact that its results have yet to be published in the scientific literature, and that other factors in addition to HAR play a role in organ rejection which is yet to be fully understood.

Imutran says that it believes its technology "is now ready to be tested in humans", and that it expects its first trial to begin next year in the United Kingdom, at the Papworth Hospital near Cambridge. John Wallwork, director of cardiac transplantation at Papworth Hospital — and also a co-founder of Imutran, set up in 1984 - says that the planned trials "will be a big step forward in the development of a genuine advance in human transplantation."

Smith says that the implications of Imu-

The French survey should begin before the end of the year, making it the second automated NEO search in the world, after the University of Arizona's Spacewatch programme at Kitt Peak. Initially, the Caussols telescope will be equipped with one charge-coupled device (CCD) detector, putting it roughly on a par with the Spacewatch telescope which discovers about between two and five NEOs per month.

Maury has already acquired nine CCD detectors and plans to have them all installed within a year, which would make his telescope by far the more powerful instrument.

Meanwhile, Maury has teamed up with astronomers at the German space agency, DLR, in an attempt to secure observing time at a 1-metre telescope at the European Southern Observatory in Chile. A Southern Hemisphere telescope would be a major advantage, as it would enable astronomers to find and track NEOs in both the northern and southern skies.

Steve Nadis

\author{
IMAGE \\ UNAVAILABLE \\ FOR COPYRIGHT \\ REASONS
} is that "HAR is no longer an issue". $\mathrm{He}$ adds: "The big debate now is, do we currently have the skills to keep the hearts functioning in people for a long time; and the only way to answer that question is to put them into people and find out."

Some researchers in the field argue that such experiments are premature. They claim in particular that more needs to be understood about other longer-term mechanisms in addition to HAR which can lead to eventual transplant rejection.

White, however, says that unexpectedly high survival levels of the monkeys given the transgenic hearts has boosted the company' confidence in moving forward. "A lot of people have said that [tackling the problem of HAR] was only the first of many hurdles," he says. "But as far as we can see, the other hurdles have not raised their head of the timeframe of our experiments."

Indeed, he is critical of those who, he claims, are holding back without warrant. "We are talking about designing a Model-T Ford, while other people are saying 'let's not go out driving until we have a Ferrari'."

Nevertheless, given the many uncertainties that remain, the optimistic tone surrounding last week's announcement has received some criticism for raising unrealistic expectations among those currently awaiting organ transplants, and encouraging the idea that human organ donors may be in less demand in the near future.

"One should not underestimate what Imutran has achieved," says Brian Pentecost, medical director of the British Heart Foundation. "At the same time, it is very important that the public does not come to believe that there is going to be a solution just around the corner, and that the need for individuals to volunteer as donors should not be lost."

White, however, firmly rejects charges that his company is guilty of raising unfair expectations - and in particular that last week's announcement via the press was 
partly motivated, as some have suggested, by the need to raise more venture capital to support further experiments.

"We have made a point of stressing that there is no way that transgenic pig hearts are going to be generally available to people within less than five years," he says, adding that his company is receiving full financial backing from the pharmaceutical company Sandoz, and that "there is no public share offer in the offing".

The decision to make the results of Imutran's experiments available to the press prior to their publication in the scientific literature, he said, was based on the fact that some media stories were already appearing following a presentation to a recent conference in Amsterdam.

At the same time, White promises that the planned clinical trials at the Papworth Hospital will be carried out "under guidelines from the regulatory authorities". If such experiments do, in fact, begin next year, then such authorities will have to work swiftly; the British government, in a move which gave all the appearances of having been precipitated by the Imutran announcement, has only just agreed to set up an advisory committee to establish an ethical framework for xenotransplantation experiments.

According to an announcement by officials of the Department of Health, made unusually during the course of last week's Imutran press conference, the advisory committee will be chaired by Ian Kennedy, professor of medical law and ethics at Kings College in London.

White argues that there are no major ethical issues to be resolved concerning the principle of using animal organs for human transplantation, pointing out that pig insulin, for example, is already used to treat diabetes. More difficult, he admits, will be deciding the criteria on which patients will be selected for the experimental treatment, although even here, he feels, some patients may be prepared to accept highly experimental treatment if it is their only prospect of survival.

But the advisory committee can still expect strong reaction from animal welfare groups. Compassion for World Farming, for example, a group which has been actively engaged in issues such as the fight against the patent on the Harvard Oncomouse, has already expressed its opposition to xenotransplantation, suggesting that the solution lies increasing the number of potential human donors - as well as encouraging life-styles that reduce the need for organ transplantation in general.

Imutran officials say that they are remaining on their guard against possible protest action from animal welfare groups. They already have a herd of about 400 transgenic pigs, which are being kept in Cambridgeshire. But the precise location of the pigs is being held secret to prevent attacks from extreme animal rights groups.

David Dickson

\section{Physicists warm to French strategy on nuclear tests}

Paris. Seen in its broad political context, more good than harm is likely to result in the long run from France's decision to carry out a final series of nuclear tests in the South Pacific. This, at least, appears to have been one conclusion to emerge from a debate among physicists held in Paris last week on the role of scientists in the internal and public debate over nuclear weapons.

Richard Garwin, IBM Fellow Emeritus at the Thomas J. Watson Research Center in New York - and the main speaker at the meeting, organized by the French Physics Association - said that the planned series of tests is "not only acceptable, but desirable, if it leads to a zero-yield comprehensive test ban treaty".

Garwin, who was an adviser to the Los Alamos weapons laboratory between 1950 and 1993, and also to US presidents John F. Kennedy, Lyndon Johnson and Richard

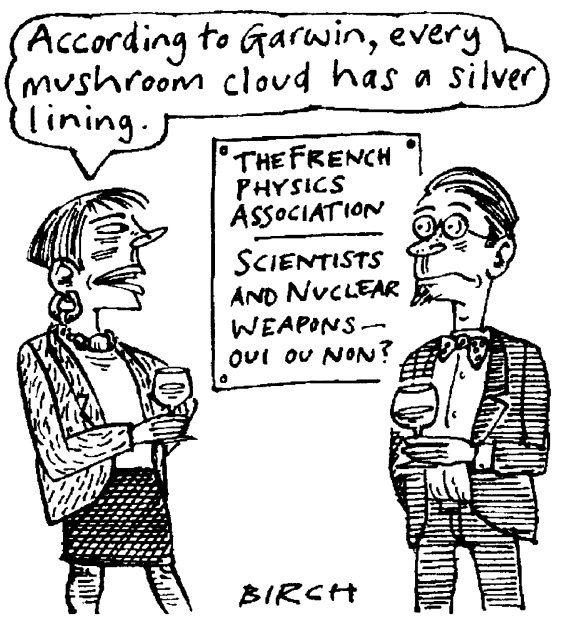

Nixon, said he was unconvinced by the French case for resuming the tests, the first of which took place two weeks ago.

But he added that, if French officials are convinced that they need the planned series of tests, then their decision to proceed will be a small price to pay for French agreement to a total test ban. There was little dissent from most of the French physicists attending the meeting, even though many had previously expressed strong criticism of the tests.

Most public attention has focused in recent weeks on the resumption of testing. But many nuclear weapons experts feel that the long-term significance of this decision may be less than that of the recent commitment by Jacques Chirac, the French president, to support a ban on all nuclear tests, no matter how small, from next year (see Nature 376, 540; 1995).

Indeed, Garwin went so far as to describe Chirac's promise, if sincere, as giving France a "leadership" role in the non-proliferation arena. He said that it has already prompted both the United States and the United Kingdom to ignore parts of their own military establishments and make similar commitments to a "zero-yield" ban.

Previously, the five nuclear weapons state members of the United Nations Security Council had been pushing for a Comprehensive Test Ban Treaty that would have allowed nuclear tests with yields up to around 1,000 tonnes (see Nature 376, 283; 1995). This socalled 'threshold' posed a greater threat to non-proliferation efforts than the French nuclear tests, argues Hubert Reeves, an astrophysicist at the Centre National de la Recherche Scientifique.

Reeves, who attended last week's meeting, has been an outspoken opponent of France's decision to resume nuclear testing. But he now says that he is "less worried" than previously about the consequences of the French decision.

According to Reeves, Chirac's commitment to a zero-yield test ban has dispelled much of the distrust created among nonnuclear weapons states by his earlier announcement to resume testing. $\mathrm{He}$ describes the gathering momentum for a total test ban as "a happy ending", and points out that this was probably influenced by the scale of public protests at French tests. "Something good always comes out of something bad", he says.

The decision to invite Garwin to be the main speaker at last week's meeting reflects the fact that US scientists have ironically played a bigger role in the internal debate in France over the decision to resume nuclear testing than the country's own scientists.

Controversy was generated earlier this summer, for example, by a joint report written by members of the US National Resources Defense Council (NRDC) and the Federation of American Scientists (FAS) - of which Garwin is vice-president - disputing the French government's justification for the planned tests.

In particular, the report argued that there was a contradiction between French claims that the existing arsenal was reliable and that two tests were needed to maintain the stockpile against the effects of ageing.

The report stimulated a lively exchange in the French press between Garwin and Jacques Bouchard, the director of the Military Applications Division of the French Atomic Energy Commission.

French scientists have obtained more than 2,000 signatures for a petition denouncing the French tests. But Reeves and others agree they have had a lower profile in the debate than their US counterparts. "I said to my colleagues, where's the spirit of '68?", says Reeves.

Declan Butler 